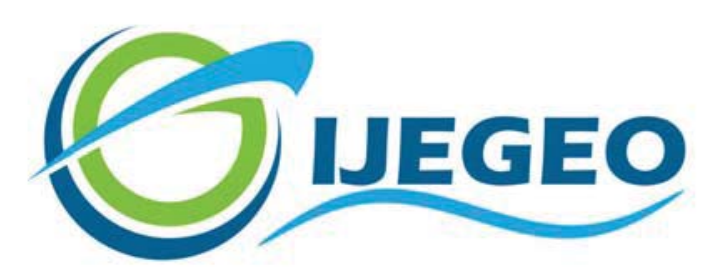

International Journal of Environment and Geoinformatics (IJEGEO) is an international, multidisciplinary, peer reviewed, open access journal.

\title{
Suitable Solid Waste Disposal Site Selection Using Geographical Information System: A Case of Debre Markos Town, Ethiopia
}

\author{
Abinet Addis MIHIRETIE \\ Chief in Editor \\ Prof. Dr. Cem Gazioğlu \\ Co-Editors Prof. Dr. Dursun Zafer Şeker, Prof. Dr. Şinasi Kaya, \\ Prof. Dr. Ayşegül Tanık and Assist. Prof. Dr. Volkan Demir
}

Editorial Committee (June 2022)

Assoc. Prof. Dr. Abdullah Aksu (TR), Assoc. Prof. Dr. Uğur Algancı (TR), Assoc. Prof. Dr. Aslı Aslan (US), Prof. Dr. Levent Bat (TR), Prof. Dr. Paul Bates (UK), İrşad Bayırhan (TR), Prof. Dr. Bülent

Bayram (TR), Prof. Dr. Luis M. Botana (ES), Prof. Dr. Nuray Çağlar (TR), Prof. Dr. Sukanta Dash (IN), Dr. Soofia T. Elias (UK), Prof. Dr. A. Evren Erginal (TR), Assoc. Prof. Dr. Cüneyt Erenoğlu (TR), Dr. Dieter Fritsch (DE), Prof. Dr. Ç; Prof. Dr. Manik Kalubarme (IN), Dr. Hakan Kaya (TR), Assist. Prof. Dr. Serkan Kükrer (TR), Assoc. Prof. Dr. Maged Marghany (MY); Prof. Dr. Micheal Meadows (ZA), Prof. Dr. Nebiye Musaoğlu (TR), Prof. Dr. Masafumi Nakagawa (JP), Prof. Dr. Hasan Özdemir (TR), Prof. Dr. Chyssy Potsiou (GR), Prof. Dr. Erol Sarı (TR), Prof. Dr. Maria Paradiso (IT), Prof. Dr. Petros Patias (GR), Prof. Dr. Elif Sertel (TR), Prof. Dr. Nüket Sivri (TR), Prof. Dr. Füsun Balık Şanlı (TR), Dr. Duygu Ülker (TR), Prof. Dr. Seyfettin Tsaş (TR), Assoc. Prof. Dr. Ömer Suat Taşkın (TR), Assist. Prof. Dr. Tuba Ünsal (TR), Assist. Prof. Dr. Sibel Zeki (TR) 


\title{
Research Article
}

\section{Suitable Solid Waste Disposal Site Selection Using Geographical Information System: A Case of Debre Markos Town, Ethiopia}

\author{
Abinet Addis Mihiretie \\ Department of Civil \& Environmental Engineering, Debre Markos University, Debre Markos, Ethiopia
}

E-mail: abinet_addis@dmu.edu.et

Received 22.08.2020

Accepted 17.09.2021

How to cite Mihiretie (2022). Suitable Solid Waste Disposal Site Selection Using Geographical Information System: A Case of Debre Markos Town, Ethiopia, International Journal of Environment and Geoinformatics (IJEGEO), 9(2):001-008 doi. 10.30897/ijegeo.784087

\begin{abstract}
In this study an effort has been made to identify suitable sites for safe disposal. For proper identification and selection of appropriate sites for solid waste disposal careful and systematic procedures need to be adopted and followed. The main objective of this research was identified the suitable solid waste disposal site by using the GIS-based approaches in Debre markos town. The present study had considered various factors like road networks; rivers, soil, slope, altitude and land use/ land cover for selecting a suitable solid waste disposal site within the study area. The relative weights of the factor were estimated using AHP and factor maps were developed by using GIS spatial operations. The final weighted factor map produced an overall solid waste disposal suitability map. The solid waste disposal site suitability map was presented in four suitability index such as highly suitable, moderately suitable, low suitable and unsuitable. The result shows that around $21 \%$ area is highly suitable for solid waste disposal site, $25 \%$ is moderately suitable, $28 \%$ of study area has low suitable and $26 \%$ area is unsuitable for solid waste disposal site.
\end{abstract}

Debre markos, GIS, solid waste disposal site

\section{Introduction}

Solid waste disposal is becoming a major global problem. Due to increasing human activity, solid waste is creating serious damage to the ecosystem and human health. Illegal dumping of urban waste in unacceptable locations (Ahmad et al., 2011) causes' damage. Uncontrolled growth of the urban population in developing countries in recent years has made solid waste management an important issue. Today municipal solid waste management is one of the most challenging issues in urban cities, which are facing a serious pollution problem due to the generation of huge quantities of solid waste (Sulemana et al., 2020; Jimoh et al., 2019; Debishree and Samadder, 2014; Troschinetz and Mihelcic, 2009).

Solid waste in Ethiopia the booming growth of cities of the developing world has outpaced the financial and manpower resources of municipalities to deal with provision and management of services, of which solid waste is the major one. Lack of these services greatly affects the urban poor, women and children who are vulnerable to health hazards. Twenty-two human diseases are related to improper solid waste management (World Bank, 1999). Moreover, its effects are also reflected in reduced productivity, low income and poor quality of life and deteriorated environment. Similar to cities of most developing countries, provision of required services lags behind the need and development of settlements in urban areas of Ethiopia. Integrated infrastructure and housing development is not widely practiced. Provision of solid and liquid waste collection and disposal is low (most urban areas lack the service). In addition to this, deterioration of the immediate environment in the households and their surrounding is increasing. With the current growth rate of urban population in Ethiopia, it is estimated that the population of most urban areas especially small urban centers is doubling every 15-25 years (Bedasa and Wondwossen, 2019). As solid waste generation increases with economic development and population growth, the amount in these urban areas will double within a similar time range. Municipalities in Ethiopia have to be prepared for this challenge (Ambaneh, 2016). An integrated urban rural development study undertaken in 1988 showed that among the eleven project towns: Addis Ababa, Akaki, Assela, Ambo, Arsi Negele, Goba, Mizan Teferri, Robe, Wolisso, Ziway, and Shashemene, only Addis Ababa had centralized waste disposal system (NUPI, 1989). The towns had no waste collection trucks; four of the municipalities assigned other vehicles to collect waste once or twice a week. Among those who have the service the coverage is very low, usually being limited to street and market cleaning. Recently, most municipalities in Ethiopia have become aware of the negative consequences of poor sanitation.

Geographical Information Systems (GIS) which are of the ability of processing and analyzing each kind of data, are of an important role for proper solid waste areas; in a word a decision support tool for determining alternative areas. Such as GIS makes it possible to include all kind of spatial technical, economic and social conditions and 
studying the results developed under different conditions. However, another important question in solid waste site selection process is to find out the more proper alternatives among the proper solid waste (Iscan and Yagci, 2015; Şener et al., 2010; Current and Ratick, 1995).

In Debre markos town the source of solid wastes from hospitals, constructions, households and commercial areas are collected and dumped, which may contain leachable and toxic compounds that are harmful to the environment and human health. The disposal system of solid waste in the town is open dumping, which is commonly carried out on areas which are not been selected following any scientific way for suitability. Majority of population in Debre markos disposed waste illegally into public places, river and ditches.

In this study, the main objective was identified a suitable solid waste disposal site in Debre markos town using
GIS techniques. Specifically identifying factors for selecting suitable solid waste disposal site; determining the relative importance of the factors for solid waste disposal site using a weighted linear combination (WLC) methods and mapping of suitable solid waste disposal site in the study area.

\section{Material and Methods Study Area}

Debre markos town is located in the northwestern part of the country at a distance of approximately $299 \mathrm{kms}$ by road from Addis Ababa on the Bahir Dar highway. The town is the center of the East Gojjam zone. According from UTM coordinate system, the location of the town is approximately between $356564 \mathrm{~m}-365423 \mathrm{~m}$ East direction and $1136757 \mathrm{~m}-11470559 \mathrm{~m}$ North direction as shown in Fig.1.

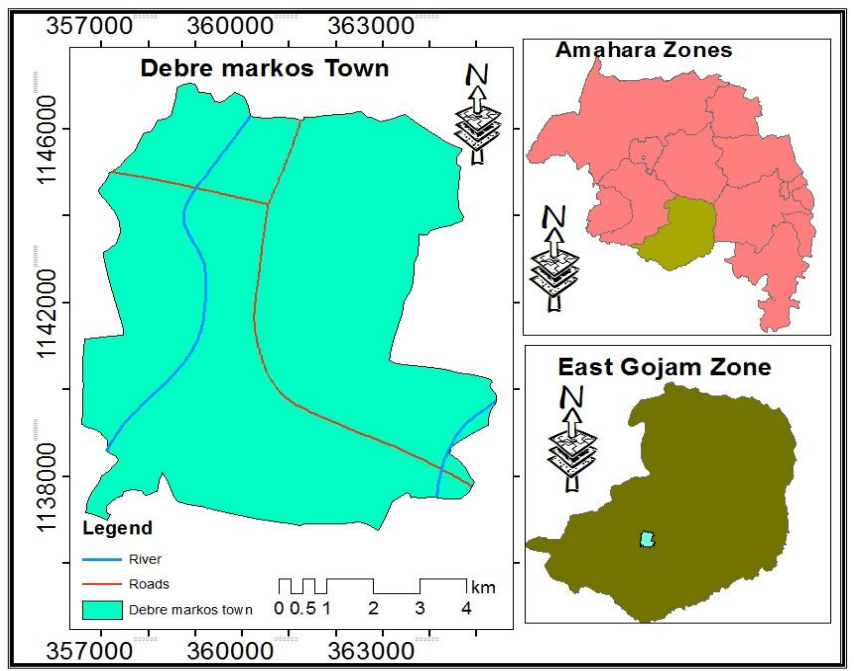

Fig. 1. Location map of the study area

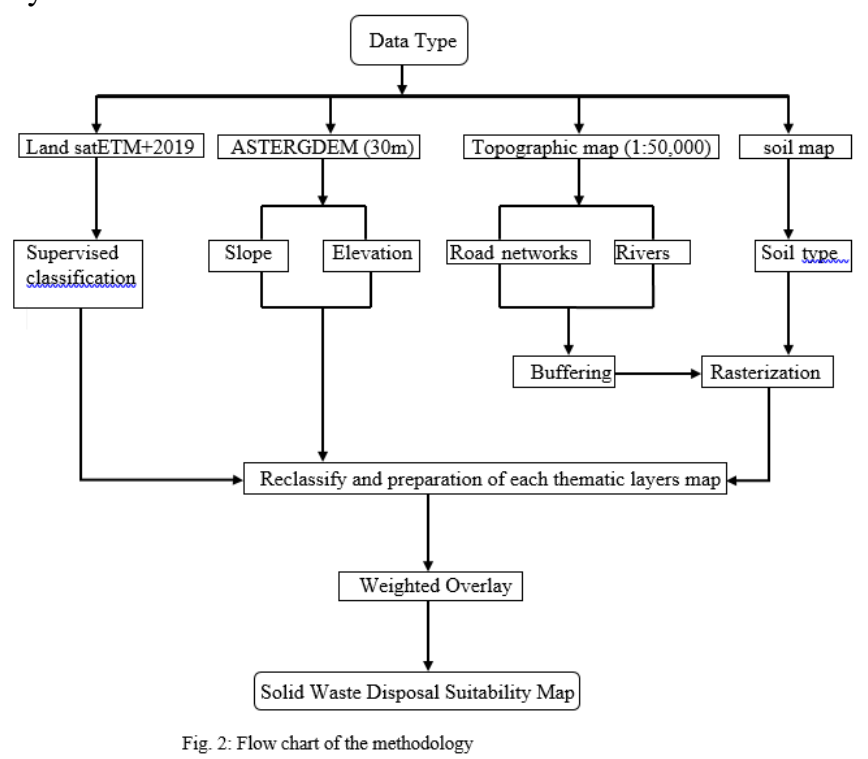

Fig. 2: Flow chart of the methodology

\section{Methods}

Debre markos town was selected to identify solid waste disposal areas. For this Multi Criteria Analysis was used for creating various layers to be used in GIS domain to produce a single output map. The weights were developed by providing a series of pair wise comparisons of relative importance. Based on experience 
and likely impact on surrounding environment different weights were assigned to all the parameters. Weighted linear combination was used to produce the suitability of solid waste disposal map. As for the final weighted factor map is a weighted linear combination of factor maps, an equation (1) as following:

Table 1: Data type and their sources

\begin{tabular}{llll}
\hline No. & Types of Datasets & Format & Sources \\
\hline 1 & Land use land cover & Raster & $\begin{array}{l}\text { Interpretation of Landsat 8 image (2019) from } \\
\text { USGS website }\end{array}$ \\
& & Raster & Interpretation of ASTER GDEM image (2019) \\
2 & Slope and Elevation & Vector, Shape file & Minister of Water and Energy, Addis Ababa \\
3 & Soil types & Vector, Shape file & Minister of Water and Energy, Addis Ababa \\
4 & Surface water & Vector, Shape file & $\begin{array}{l}\text { Interpretation the study area of Topographical } \\
\text { map from (EMA), Addis Ababa }\end{array}$ \\
\hline 5 & Road network & & \\
\hline
\end{tabular}

\section{Results and Discussion \\ Factors for Identify Solid Waste Disposal Site Slope}

Slope suitability was an important factor in considering a solid waste disposal site selection. Slope refers to the measures of the rate of change of elevation at a surface
$\mathrm{S}=\Sigma$ wi xi where, $\mathrm{S}=$ suitability, wi = weight of factor $\mathrm{i}$ and $\mathrm{xi}=$ factor map $\mathrm{i}$.

\section{Data Type and Source of Data}

For this study different types of datasets were integrated within GIS environment to come up with final output of solid waste site selection in Debre markos Town. The datasets used are tabulated below in (table 1).

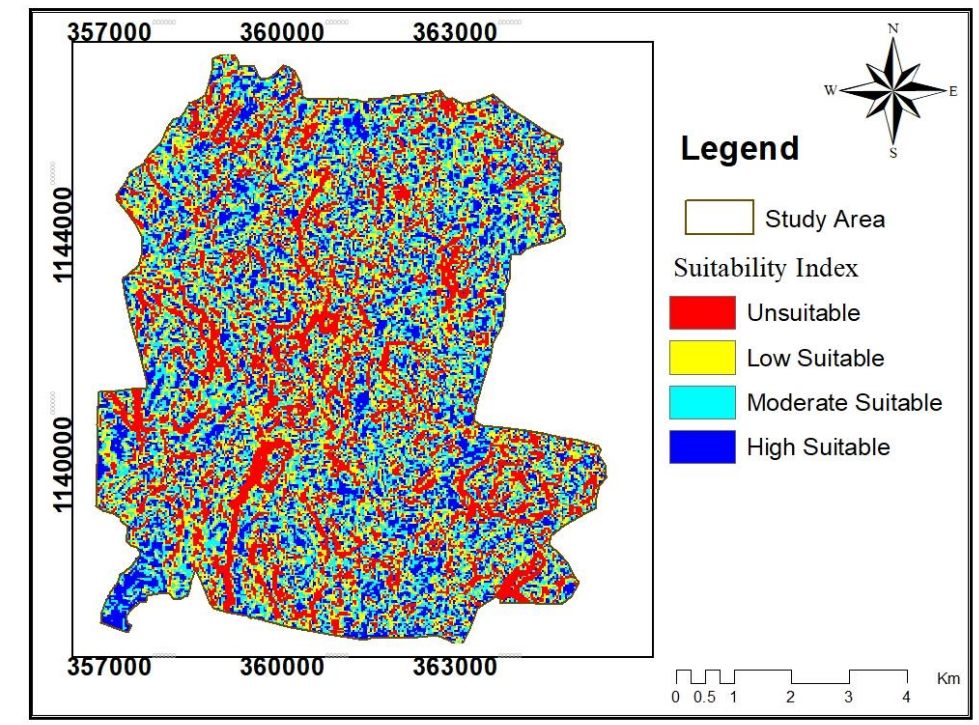

Fig. 3: Slope factor map.

Table 2: Classification, ranking and weighting of Slope factor.

$\begin{array}{lcccc}\text { Factor } & \text { Weight } & \text { Class } & \text { Rank } & \text { Degree of disposal } \\ \text { Slope (Degree) } & & 0-10 & 4 & \text { High Suitable } \\ & 0.10 & 10-15 & 3 & \text { Moderate Suitable } \\ & & 15-20 & 2 & \text { Low Suitable } \\ & & >20 & 1 & \text { Unsuitable }\end{array}$

\section{Altitude}

Altitude was generated from the ASTER GDEM data. The altitude of the study area generally ranges between $2240 \mathrm{~m}$ and $2514 \mathrm{~m}$. Altitude is a basic parameter to build a landfill. Areas with too high altitude are not suitable location and normally expressed in percent or degree slope. The too steep slope sites will increase the cost of excavation and embankment. The appropriate slope for constructing a landfill is about $5-15 \%$ because too steep of a slope would make it difficult to construct and maintain, while too flat of a slope would affect the runoff drainage (Abdelhakim et al, 2016) Fig.3/Table 2.

$>20$

for solid waste disposal site because of it is difficult to permit gravity flow (Kao and Lin, 2005). The ideal places for landfill should be located at a low altitude in order to permit gravity flow (Fig 4/Table. 3). 


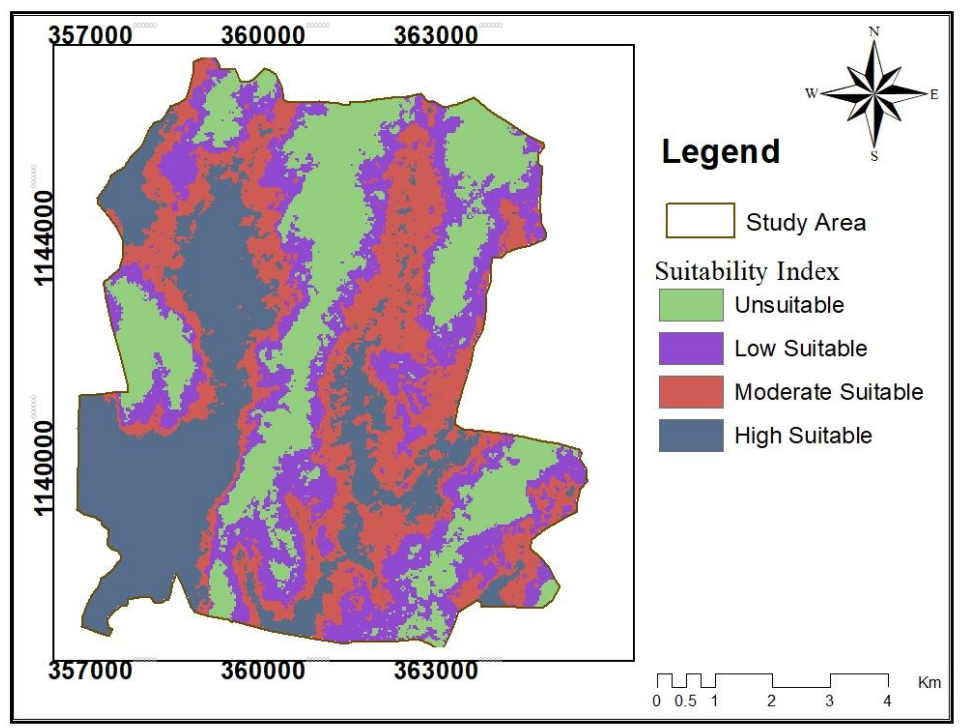

Fig. 4. Altitude factor map

Table 3. Classification, ranking and weighting of Altitude factor

$\begin{array}{ccccc}\text { Factor } & \text { Weight } & \text { Class } & \text { Rank } & \text { Degree of disposal } \\ & & 2240-2383 & 4 & \text { High Suitable } \\ \text { Altitude (meter) } & 0.10 & 2383-2411 & 3 & \text { Moderate Suitable } \\ & & 2411-2436 & 2 & \text { Low Suitable } \\ & & 2436-2514 & 1 & \text { Unsuitable }\end{array}$

\section{Distance from Rivers}

The solid waste disposal site should not be placed within surface water to protect surface water from contamination by leachate (Abdelhakim et al, 2016). Amhara National Regional State has established the Regional Hygiene and Environmental Executive
Committee, which has issued regional environmental sanitation regulations (No.16/2000); it clearly states that the solid waste disposal should not be dump to any water surface like river, stream, Lake etc. In the study area, Chemoga River is one of the main surface water. Researchers have suggested a distance up to $500 \mathrm{~m}$ away from surface wate (Kontos et al., 2005), Fig.5/Table 4.

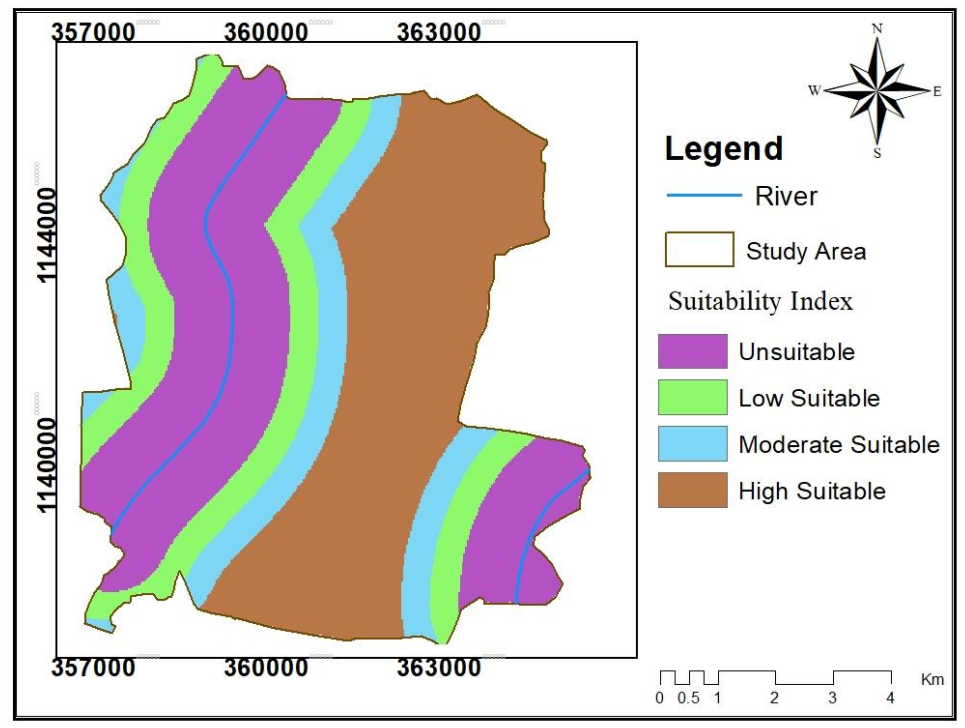

Fig. 5. Rivers factor map 
Table 4: Classification, ranking and weighting of Altitude factor

$\begin{array}{ccccc}\text { Factor } & \text { Weight } & \text { Class } & \text { Rank } & \text { Degree of disposal } \\ & & 0-1000 & 1 & \text { Unsuitable } \\ \text { River (meter) } & 0.15 & 1000-1500 & 2 & \text { Low Suitable } \\ & & 1500-2000 & 3 & \text { Moderate Suitable } \\ & & >2000 & 4 & \text { High Suitable }\end{array}$

\section{Distance from Road Networks}

The road is one of the important factors in considering a solid waste disposal site selection. There is no specific rule of what should be the best distance to place the solid waste disposal site. Most studies suggested that the disposal site should be located within a $500 \mathrm{~m}$ buffer from the existing roads (Shahmoradi and Isalou, 2013). However, planners may prefer to give an aesthetic concern when deciding a location of solid disposal site. In addition, the site should not be close to the existed road networks that affects the public health, (Fig6/Table $5)$.

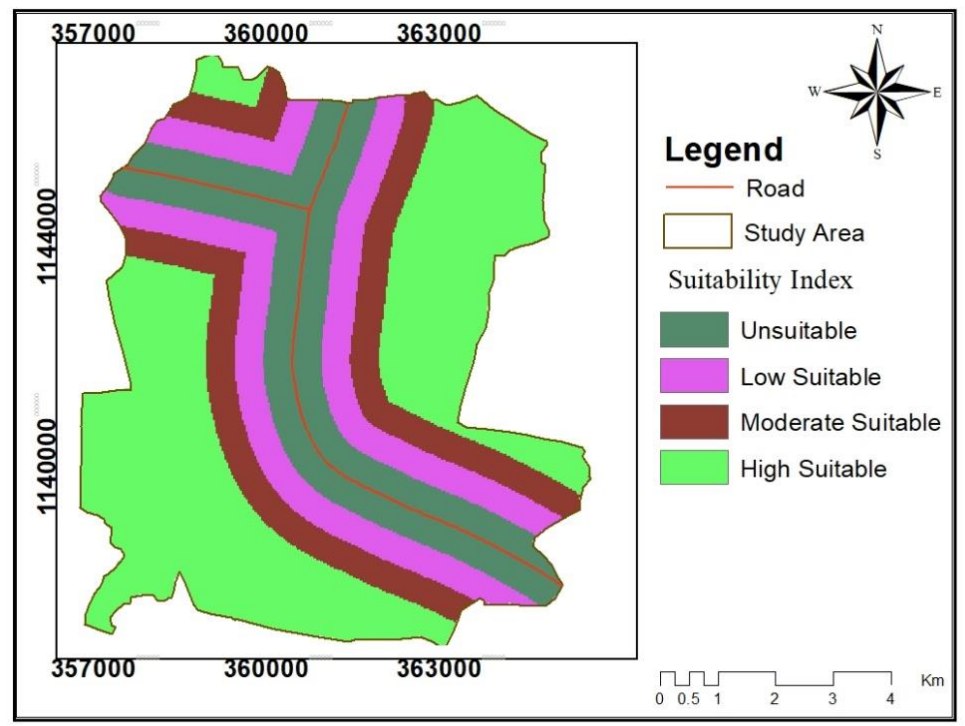

Fig. 6. Road networks factor map

Table 5: Classification, ranking and weighting of Road networks factor

\begin{tabular}{cccccr} 
Factor & Weight & Class & \multicolumn{2}{c}{ Rank } & \multicolumn{2}{c}{ Degree of disposal } \\
& & $0-500$ & 1 & 2 & Unsuitable \\
Road Networks (meter) & 0.20 & $500-1000$ & $1000-1500$ & 3 & Low Suitable \\
& & $>1500$ & 4 & High Suitable
\end{tabular}

\section{Land use Land cover}

In the present study land use/land cover was analyzed from Landsat 8 image data for the solid waste disposal site selection. In the study area, there are five major land uses such as water body, built-up area, forest and agricultural land and vegetation areas. By reviewing different literature, it was advisable to select land, it was occupied by bare and grass lands a high suitable area for solid waste disposal (Fig.7/Table 6). 


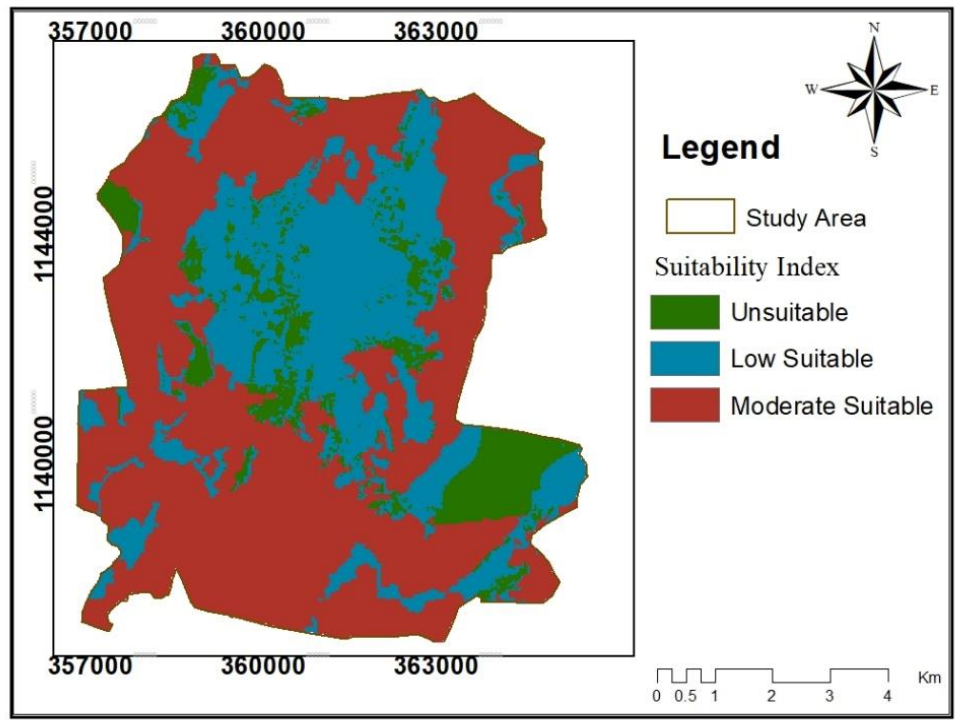

Fig. 7: Land use Land cover factor map

Table 6: Classification, ranking and weighting of Land use Land cover factor

\begin{tabular}{|c|c|c|c|c|}
\hline Factor & Weight & Class & Rank & Degree of disposal \\
\hline \multirow{3}{*}{ Land use Land cover } & \multirow{3}{*}{0.35} & Water body and forest & 1 & Unsuitable \\
\hline & & Built up and vegetation area & 2 & Low Suitable \\
\hline & & Agricultural area & 3 & Moderate Suitable \\
\hline
\end{tabular}

\section{Soil Types}

There were three type of soils texture in the study area based on FAO (2006) classification such as eutric nitisols, Pellic vertisols and chromic vertisols. Soil should be of sufficiently low permeability to significantly slow the passage of leachate from the site. The higher the permeability of the textured unit, the lower is the site suitability for landfill practices and the higher is its vulnerability. In the present study, soil texture was classified into three zones according to the texture unit of permeability characteristics (Fig.8/Table 7).

\section{Overlay Analysis and Identifying Suitable Areas}

To determine the suitable areas for solid waste disposal sites, there are six factors were considered. The factors are surface water; road networks, soil texture, land use land cover, slope and altitude. Each factor thematic map was prepared using ArcGIS spatial analyst tools, and prepared maps were converted into raster format. The overlay analysis of the final weighted factor map was produced the final suitable solid waste disposal site map was prepared using ArcGIS software by the following principle:

$$
\text { Suitability Map }=\Sigma[(\text { Factor map * weight })
$$

Suitability index $=([$ surface water map $] * 0.15+[$ land use map] ${ }^{*} 0.35+\left[\right.$ slope map] ${ }^{*} 0.10+$ [altitude map] ${ }^{*} 0.10$ $+[$ soil map $\left.] * 0.10+[\operatorname{road} \text { map }]^{*} 0.20\right)$

The result of weighted factor map in the ArcGIS software reveals four suitability indices for the municipal solid waste dumping site of Debre markos town. These are unsuitable, low, moderate and high suitable. 


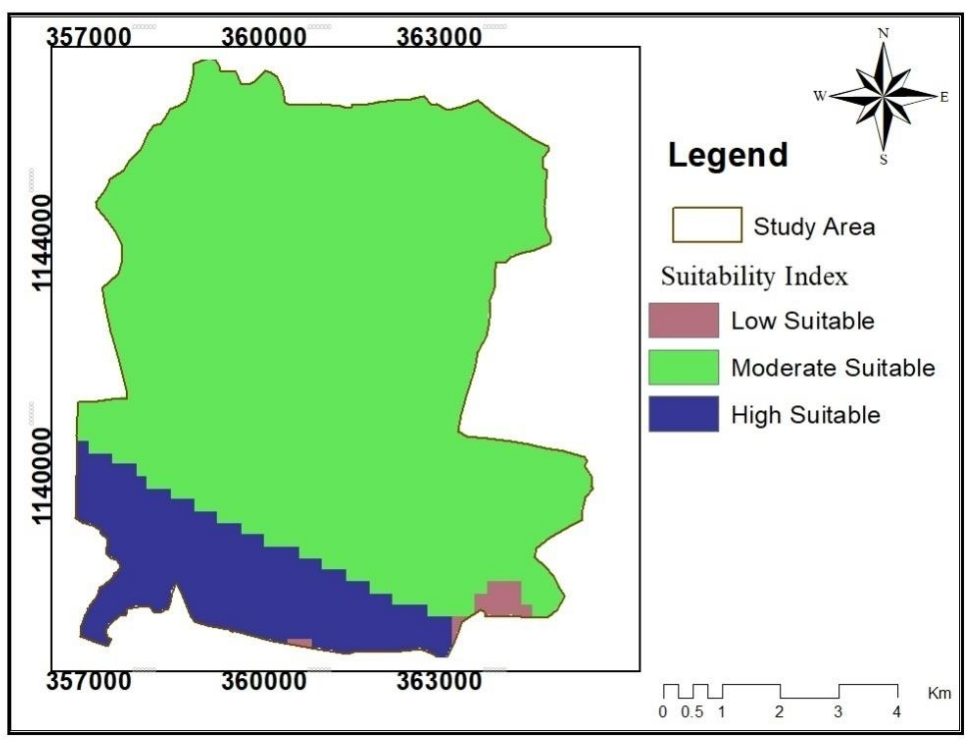

Fig. 8: Soil types factor map

Table 7: Classification, ranking and weighting of Soil types factor

$\begin{array}{ccccc}\text { Factor } & \text { Weight } & \text { Class } & \text { Rank } & \text { Degree of disposal } \\ & & \text { eutric nitisols } & 2 & \text { Low Suitable } \\ \text { Soil types } & 0.10 & \text { Pellic vertisols, } & 3 & \text { Moderate Suitable } \\ & & \text { Chromic vertisols } & 4 & \text { High Suitable }\end{array}$

The area coverage of each suitability index of the sites was calculated in ArcGIS environment showed that $(26 \%)$ of the study area is unsuitable for solid waste disposal site as the areas are environmentally unfavorable and economically impracticable to be proposed as solid waste disposal site. This unsuitable area include close to surface water (area with a $500 \mathrm{~m}$ buffer zone), areas with steep slope (>200), a higher altitude $(>2514 \mathrm{~m})$, water bodies and forest areas and close to road networks (with a $500 \mathrm{~m}$ buffer zone), respectively. The main advantage of these areas unsuitable was to minimize their negative effects of on environment and public health as well as to minimize the cost of construction and maintenance of the land fill. However, $(27 \%)$ of the area was low suitable and the area of $(25 \%)$ moderate suitable. Out of the remaining areas of $(21 \%)$ are high suitable, these areas are preferable for solid waste disposal sites, because of their minimum effect on environment, public health and cost effective than other parts of the study area (F,g 9/ Table 8).

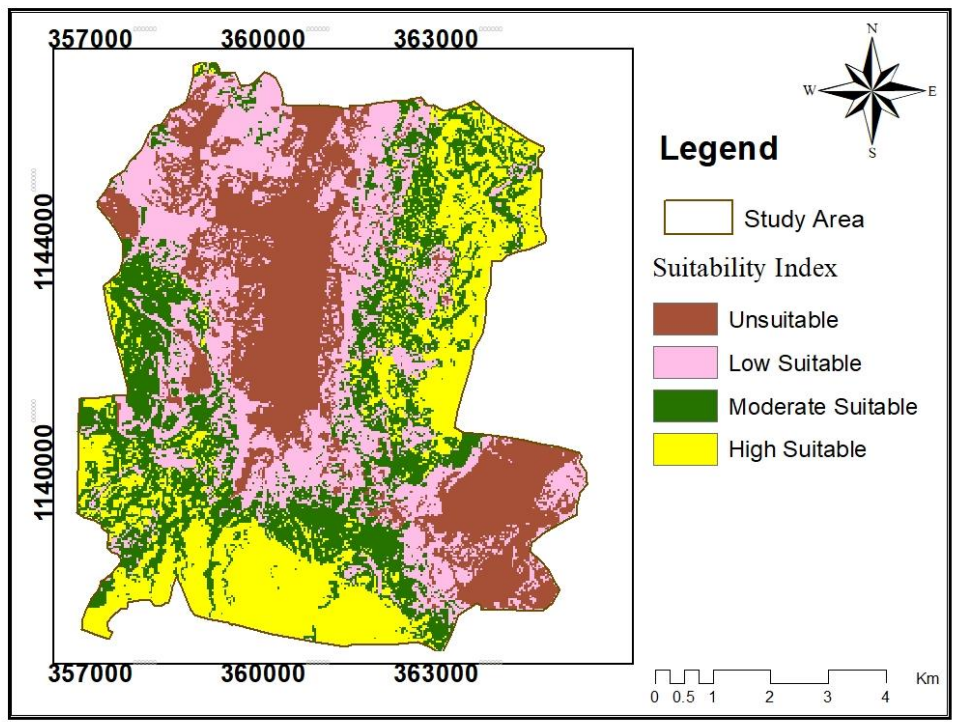

Fig. 9: Solid waste disposal suitability Map of Debre markos town 
Table 8: Statistical analysis for the solid waste disposal site suitability

$\begin{array}{lcc}\text { Suitability Index } & \text { Area in }\left(\mathrm{km}^{2}\right) & \text { Area in }(\%) \\ \text { Unsuitable } & 233.51 & 26 \\ \text { Low Suitable } & 246.09 & 28 \\ \text { Moderate Suitable } & 228.04 & 25 \\ \text { High Suitable } & 192.35 & 21 \\ \text { Total } & 899.99 & 100.00\end{array}$

\section{Conclusions}

The analysis factors were used in the identification of suitable sites for solid waste disposal in Debre markos town using the GIS techniques. Currently solid waste is disposed at open spaces near to outside the municipal boundary impact on health hazards for the rural settlements. Geographic information system tools widely used to assist the identification of suitable sites for solid waste disposal. In this study, Selection of suitable site depends on a number of factors were considered. The factors are slope, altitude, road networks, rivers, soil types and land use land cover but some other factors like ground water, settlements, and geology that may also affect the sitting of suitable sites but they were not included in the present study due to data limitations. After produced the final weighted map, the high suitable solid waste disposal sites were identified in the study area. The high suitable solid waste disposal sites were located in the southern and eastern part of a town.

\section{References}

Abdelhakim El Maguiri, B. K. (2016). Landfill site selection using GIS, remote sensing and multicriteria decision analysis: case of the city of Mohammedia, Morocco, doi. 10.1007/s10064-016-0889.

Ahmad A., B. A. (2011). GIS-Based Weighted Linear Combination Analysis and Remote Sensing Techniques to Select Optimum Solid Waste Disposal Sites within Mafraq City, Jordan. Journal of Geographic Information System; 19(3): 267-278. .

Ambaneh M. (2016). Solid Waste Disposal Site Selection Using Gis And Remote Sensing: For Mojo Town, Ethiopia.

Current, J.; Ratick, S. (1995). A model to assess risk, equity and efficiency in facility location and transportation of hazardous materials. Locat. Sci. 3, 187-201

Iscan, Yagci, O. (2015). Selection of Solid Waste Landfill Site Using Geographical Information System (GIS). 9(8).

Kao J. and Lin H.Y. (2005). Grid-based heuristic method for multifactor landfill siting. Journal of Computing in Civil Engineering, 19(4): 369-376. .

Kontos T. D., K. D. (2005). MSW landfills with a spatial multiple criteria analysis methodology, Waste Manag; 25:818-832. .

Jimoh, R., Moradeyo, A., Chuma, V., Olubukola, O. Yusuf, A. (2019). GIS Based Appraisal of Waste Disposal for Environmental Assessment and
Management in Mainland Area of Lagos State, NG. International Journal of Environment and Geoinformatics, 6(1), 76-82, doi: 10.30897/ijegeo. 476449

Samadder, D. K. (2014). Application of GIS in Landfill Siting for Municipal Municipal Solid Waste. 4(22493131, 4(1), 37-40). .Shahmoradi B.and Isalou A. (2013). Site selection for wastewater treatment plant using Integrated fuzzy logic and multicriteria decision model: A case study in Kahak, Iran. Adv Environ Health Res; 1(1): 51-61.

Sulemana, A., Forkuo, E. K., Arthur, E. T., Agyeigyamfi, K., Otchere-darko, E., Ayaim, M. K. (2020). Multi-Criteria Selection of Suitable Institutional Solid Waste Collection Sites: A Case of KNUST Campus, Kumasi, Ghana, International Journal of Environment and Geoinformatics, 7(3), 372-380, doi. 10.30897/ijegeo.696335.

Şener, ,S., Sener, E.; Nas, B.; Karagüzel, R. (2010). Combining AHP with GIS for landfill site selection: A case study in the Lake Beysehir catchment area (Konya, Turkey). Waste Manag. 30, 2037-2046.

Troschinetz, A.M.; Mihelcic, J.R (2009). Sustainable recycling of municipal solid waste in developing countries. Waste Manag. 29, 915-923

Wondwosen M., Bedasa A. (2019). Suitable Solid Waste Disposal Site Selection Using Geographical Information System (GIS): A Case of Debre Berhan Town, Ethiopia. 7(1). American Journal of Environmental Protection, 7(1), 17-23 . 